\title{
THE GENUS DIELLIA AND THE VALUE OF CHARACTERS IN DETERMINING FERN AFFINITIES ${ }^{1}$
}

\author{
Warren H. Wagner, Jr.
}

IN THE CURRENT renaissance of fern taxonomy it would seem important to emphasize the nature and relative value of the characiers which can be used as evidence of relationship. Certain allegedly "conservative" characters, especially features of the sori, the characteristic aggregations of sporangia- such as their posiiion in relation to the veins and leaf margins, their outlines, and protective indusiahave frequently been used as absolute criteria of affinities in the higher leptosporangiate ferns. Another character which has frequently been employed is leaf form - the outline of the blades and leafie:s, the venation pattern, and the degree of dissection. These are conspicuous characiers, easily seen with the naked eye or under a hand lens. But, unfortunately for the superficial observer, the ferns show numerous and striking undoubted examples of parallel or convergent evolution in regard to these gross features. In the case of leaf form, the well-known "reniform ferns," for ins:ance, all have leaves which are nearly alike in appearance; but these are entirely unrelated ferns, as illustrated by such species as Adiantum reniforme, Pterozonium reniforme, Cardiomanes reniforme, and Lindsaea reniformis. The sorus, in spite of the fact that much of our classification has been founded on it, is itself equally liable to parallel or convergent evolutionary changes. Indeed, at one time practically all ferns which possess round sori but no indusia were placed in "Polypodium"; and ferns in which the sporangia covered the dorsal pinna surfaces were put in an all-inclusive genus, "Acrostichum," but now it is evident in case after case that this was an artificial and unnatural disposition. Even so recently as 1928, Bower considered the familiar genus Athyrium as being closely related to Asplenium because these two genera posse:s approximately the same soral type. However, information available now on such varied characters as scale structure, stipe anatomy, sporangial features, and cytology in the respective genera, rather firmly establishes the fact that the gross soral resemblance is probably only a coincidence, an example of convergent evolution.

The purpose of this paper is to discuss and on

1 Received for publication September 3, 1952.

This manuscript was prepared at Harvard University during the tenure of a Gray Herbarium Fellowship, and is based on a paper given in a joint Symposium of the American Society of Plant Taxonomists and the American Fern Society on the "Classification of Ferns" held at the 1950 meetings of the A.I.B.S. in Columbus, Ohio. Most of the factual information used here is drawn from investigations made in the Department of Botany, University of California, Berkeley, and reported in a monograph of the genus Diellia (Wagner, 1952). It is a pleasure to express thanks for help and suggestions to Professors Lincoln Constance, E. B. Copeland, A. S. Foster, and Reed C. Rollins. occasion to suggest the relative value of certain characters in the taxonomy of ferns, and to use as a specific example the genus Diellia of Hawaii. This genus seems to be an ideal choice for a symposium on fern classification because it has been placed at one time or other in association with no less than four different assemblages of ferns-groups which are now interpreted as belonging to four separate families. Such authors as Moore (1857), Hillebrand (1888), Christensen (1925), and Bower (1928) regarded Diellia as being a relative of Lind. saea, the latter genus now construed to be a mem ber of the Pteridaceae. Hooker and Baker (1883) and others associated Diellia with Dictyoxiphium, which Copeland (1947) has recently shown to belong to the Aspidiaceae. Arbeláez (1928), Holttum (1949), and others placed it with such genera as Davallia and Nephrolepis, both of the Davalliaceae. In 1929 Copeland adduced evidence that Diellia is actually related to the family Aspleniaceae. But in all except the last interpretation of its affinities, the sorus of Diellia was the primary hasis of comparison. In this genus the sorus is located in the marginal position and the indusium opens outward to the pinna margin, just as it does in Lindsaea and the genera related to that genus, as well as in $D a$ vallia and its immediate relatives, and also in certain species of Nephrolepis. According to Bower, in the phylogeny of those ferns which he considered to be related to Diellia, the sorus occupied just such a marginal position originally; and along various lines of advancing evolution, the sorus was considered to have "slid" to the dorsal laminar surface. Bower divided the ferns into a "marginal series" and a "superficial series," and after a study of preserved material from Hawaii, he placed Diel. lia among the marginal ferns, along with the lindsaeoid ferns and the davallioid ferns (1928). A fern genus which has been interpreted so variously as Diellia represents an obviously difficult taxonomic problem, but similar situations are repeated in numerous other genera, and these greatly need reinvestigation. The disagreement which centered around the interpretation of Diellia could only be resolved by an exhaustive examination of all its characters that could be studied, and by looking at the genus from the broadest possible standpoint. It is now evident from the study of Diellia and from comparing it with other cases that we do not actually know a priori what is "conservative" and taxonomically dependable as evidence in any particular line of evolution. It seems necessary and obvious, therefore, to adopt a procedure involving a total comparison of all the available characters of ferns if we are accurately to determine their rela- 
tionships. As Dr. Copeland has indicated, we are required to study and compare the whole plant. When this viewpoint is adopted it becomes apparent that many characters have been overlooked or have not been exploited by workers of the past. The following discussion may serve to illustrate how valuable some characters can be as sources of evidence.

To the extent that they may be analyzed, the habitats of ferns may, in some instances, contribute at least an inkling, however small, to their complex comparative physiology. And whether it be taxonomically revealing or not, their ecology should be investigated as a possible source of information. Some of our lack of information on habitat is accounted for by the lamentable practice of making collections entirely without ecological data. In the present problem, fortunately, there is a considerable amount of information at hand. Diellia is a genus comprising species which occur always in dry, shaded, rocky situations, in wooded but arid gulches, and which apparently can tolerate but little competition from other ground-story ferns and flowering plants (Wagner, 1950). On the other hand, Lindsaea and its relatives are ferns primarily of the wet forest and damp stream banks. Such species or relatives of Lindsaea as do occur in dry places tend to be "sun-ferns," tolerant of more or less direct insolation (for instance, Lindsaea ensifolia and Sphenomeris chusana). Davallia and related genera are obligate or facultative epiphytes, a condition entirely unknown in any species of Diellia. While the large and diverse genus Asplenium in the tropics has a broad amplitude of ecological situations among its various species-groups, there is one of its groups, that of the "rock-spleenworts" so frequent in temperate climates, that has habitat requirements as a whole rather conspicuously similar to those of Diellia. Evidence drawn from the ecological preference of these ferns could in this case be correlated with the following features in framing a basis for comparison.

The spores of ferns would naturally be expected to provide valuable characters in taxonomy, although their use in the literature has not been extensive. Spores are particularly useful structures in the investigations of the paleobotanist. Structure among different types of fern spores is well diversified, but there are roughly two basic types, the tetrahedral and the bilateral or elliptic, and various modifications of these, such as spores with conspicuous scars or crests, and spores which are called globose. The structure of the exospore wall is characteristic of species in some genera, frequently being distinctively sculptured. A perispore, or additional outer envelope deposited by the tapetum, is present generally in certain genera and families. Many erroneous hypotheses of inter-relationship of the past might have been avoided by the inspection of spore characters alone. In Diellia the sports are of the bilateral type, with the proximal side of the exospore shallowly concave and the distal more strongly convex. The exospore itself is colorless, smooth and hyaline, but it is surrounded by a rugose, brown-pigmented perispore and has dark "perisporial spines." The presence of a perispore by itself stands in sharp contrast to the ferns of the lindsaeoid affinity, for in the latter a perispore is entirely absent. In addition the lindsaeoid spores are tetrahedral in form. Such davallioid examples as Davallia and Nephrolepis possess the elliptic spore outline as in Diellia, but the perispore is also absent here, and the exposed exospore wall surface is sculptured. Among the asplenioid ferns, and especially in certain of the rock-spleenworts, the spores almost exactly match those of Diellia in structural details and pigmentation.

The study of the morphology of the fern gametophyte in laboratory cultures has recently been stimulated by the new phylogenetic and taxonomic investigations of ferns. There is still too limited knowledge of this generation to suffice for its broad evaluation as a character in taxonomy, although there is little question that contributions have been and will be made from studies of this generation, as has already been indicated by the researches of Stokey (1951). The peculiarities of these simple, usually haploid, plants which seem especially to offer sources of comparative evidence are the following: (1) mode of germination, (2) cell plate formation, (3) structure of gametangia, and (4) presence and nature of the haploid trichomes. But to adopt the view of Orth (1936), that the system of fern classification should be replaced by a "natural one" based on the gametophyte, is not warranted and is inconsistent with the ideal of comprehensive total comparison as the basis for taxonomy. In the study of Diellia there is at present a severe restriction in the utilization of this character because of the absence or paucity of studies of the gametophytes of the other genera involved. However, it was found that the prothallial grandular hairs of Diellia, although somewhat unique, resemble closely those of the genus Ceterach, a plant of rock-spleenwort affinities, and at least one example of the group of Asplenium trichomanes. This fact contributed to the general correlation of evidence.

The young sporophytes of ferns show such distinctive early leaf forms that there is little doubt that this feature also affords taxonomic evidence. Related ferns with very different mature fronds may have strikingly similar early fronds. Such different and peculiar types of early leaves as those of $O s$ munda, Pteridium, Dipteris, Vittaria, and Schizaea illustrate the wealth of forms which exist. The progressive stages of the juvenile leaves, however, must be taken into consideration in making comparisons. An over-simplified separation of the leaves into such "types" as "cotyledons," "juvenile leaves," and "adult leaves" or similar systems, is not justified, nor are these categories adequate, as can be demonstrated by an examination of Diellia. There is as 
much diversity in the potential form of initial leaves produced by embryos as there is in the fifth or sixth leaves later produced on the young stem. Indeed, the sixth leaf may, under certain "starved" conditions, be simpler than typical initial leaves. Therefore, the leaves from a number of young rhizomes must be collected, and arranged according to increasing blade complexity if the changes in venation and leaf-outline are to be properly described and understood. A useful technique for doing this consists of clearing the leaves and making tracings of their outlines and venation patterns by the use of a photographic enlarging device. In Diellia the initial leaves have one to four vein terminations along the margins of the blades and the arrangement of the veins follows a dichotomous plan up to stages with as many as 16-18 vein terminations. Blade division, or pinnation, does not take place in Diellia by any evident process of promoted or emphasized alternate dichotomies (the socalled "overtopping"), but occurs merely by the progressive elongation of the apex and the intercalation of lobes or pinnae below and to either side, and the consequent venation changes of the base of the blade. In the only examples of Lindsaea and Davallia available for comparison, the venation patterns become pinnate in plan at very simple stages, i.e., when there are only 3-5 vein terminations; and in Nephrolepis the juvenile leaves have pinnate venation from the outset. The capacity for continuation of dichotomously organized venation through stages with relatively numerous veins is a characteristic noted among the Aspleniaceae, and this is a point of resemblance with Diellia. The young sporophyte leaves of Ceterach spp. especially resemble those of Diellia.

The anatomy of fern roots is usually assumed to be simple and uniform, and no evidence to the contrary has been adduced. Whether this is truly the case or is the result of the lack of intensive study is a question which should be investigated. Root hair structure may possibly afford a source of taxonomic evidence which can be exploited. The anatomy of fern stems or "rhizomes," which may be readily examined even by simple hand-sectioning techniques, is relatively familiar among the taxonomic features of ferns, although even stem structure is by no means thoroughly known in ferns at large. In the comparative investigation of Diellia it was revealed that of all the supposed relatives of this genus, only certain ones of the Aspleniaceae have the same compact and erect, radially constructed, and typically dictyostelic condition found in Diellia. The rhizomes of typical Davalliaceae contrast strongly in being of the creeping type, and in having a dorsiventral structure, with highly complex "dissected dictyostely." The rhizomes of Lindsaea and its relatives are also of the horizontal type, but the vascular elements are arranged in protosteles or solenosteles.

The paleae or scales of fern stems are highly characteristic and have been used by taxonomists for many years. The scales occur abundantly at the growing tip of the stem, where they perform the same function as bud-scales around the shoot and delicate leaf primordia. The taxonomic value of these structures is evident not only at the specific level in the classification of ferns but at the generic and family levels as well. Nevertheless, in the case of Diellia this feature was repeatedly overlooked or misinterpreted. Arbeláez (1928) in his anatomical study of Diellia erroneously likened its scales to those of Davallia. Scale structure in Diellia was analyzed correctly and properly correlated only by Copeland (1929). The scales are long-triangular and attached basally to the stem apex along a line. Their cell structure is highly characteristic as the lateral walls of the numerous cell rows are thickened by a heavy deposition of secondary-wall material at the same time the superficial walls remain completely unmodified and hyaline. The cell-plate of the scale therefore appears as a latticework, and is described as "clathrate." The genus Lindsaea and its related genera contrast strikingly with Diellia in this important character, having scales which are simple in structure, comprising only one to several rows of cells at the base, and the cells uniformly pigmented a golden or brown color on all walls, both lateral and facial. The davallioid ferns, on the other hand, have scales which are as complex in structure as those of Diellia, but their cells are uniformly pigmented on all walls, and the attachment of the scales is peltate, i.e., attached more or less centrally on a rather conspicuous, narrow pedestal. Holttum's description (1949) of the scales of the Aspleniaceae as peltate is apparently based on faulty observation of scales in this family which are so strongly cordate at either side of their insertion that they appear to be peltate. No examples of truly peltate scales (such as those of the davallioid ferns) were found among the Aspleniaceae; in a large number of them, in fact, the scales are very much like those of Diellia in outline and attachment. What is perhaps more significant is the fact that the detailed cellular structure of the aspleniaceous scales is just as it is in Diellia, i.e., with the clathrate secondary-wall condition. In the present case, therefore, this character proved to be a valuable point of comparison.

The leaf axis is another feature which has already been utilized by taxonomists, both its superficial and its internal structure. There are many types of cross-sectional anatomy of petioles and midribs as well as configurations of the surface layers which characterize different ferns. Characters of the leaf axis may well be found to be one of the most useful keys to affinities among ferns, especially if the size factor be adequately considered. Softening techniques may be required for sectioning in the detailed study of petioles, although in some fern groups the sparsity of sclerenchyma sometimes permits hand-sectioning. In Diellia petiolar anatomy 
not only assisted in establishing the relationships of the genus to Asplenium but pointed specifically to the species-group of "black-stemmed" rock-spleenworts as typified by $A$. trichomanes. The stipes and rachises of Diellia have ridged adaxial surfaces, heavily sclerified and black-pigmented outer cortical and surface cell layers, and the type of monostelic vascular structure which Ogura (1938) has termed the "Marsilea-type," with two flat but curved traces fused a short distance above their abaxial edges. On the other hand, the lindsaeoid and davallioid ferns which were formerly assumed to be related to Diellia tend to have green surface cell layers, and the type of leaf-axis stele which has been called the "Loxsoma-type," a V- or U-shaped cross-sectional pattern with expanded adaxial shanks. Only the rock-spleenworts, of the Aspleniaceae, have the same type of leaf-axis stele as Diellia; the other asplenia have the distelic (but probably closely related) condition known as the "Asplenium-type" of crosssectional pattern. There has been some misunderstanding of this character in the present connection; for instance, Holttum considered that fusion of two main vascular strands near the top of the stipe occurs in Davallia just as it does in Asplenium, but the actual fusion processes are quite different. In Davallia and its relatives fusion occurs not well above the abaxial ends of the xylem strands as in Asplenium, but preciselv at the abaxial ends. It is possible that structure of the leaf-axis stele is more useful in demonstrating affinities at the generic and subgeneric levels. and that the outer cortical lavers and surface lavers of the stipe and rachis are more revealing at the species level. In Diellia. for example. the stele is most significant in indicating the group of Asplenium species to which it is most nearlv related, but the structure of the surface cell layers is more valuable in delimitation of species within the genus.

Over-all leat structure of ferns is well known to be phylogeneticallv nlastic in some cases. As an illustration, there is little roubt that Camptosorus rhizonhyllus, the common "walkin -fern," with its peculiar caudate, simole, net-veined leaves, is closely related to and probablv derived from rock-spleenworts of the type of Asplenium trichomanes, with narrow pinnate fronds and free veins. (In fact, the genus Camptosorus hvbridizes readily in nature with certain, entirelv different-appearing members of this group, notahlv Asplenium platvneuron and A. rufa-muraria, and probably with others.) As might be expected, the outline and degree of dissection of fern leaves has probablv nroduced as much confusion as it has reliable evidence in the interpretation of fern affinities. In general frondhabit species of Diellia are remarkably similar to species of genera in the lindsaeoid group; indeed Isoloma jamesonioides resembles individual plants of Diellia pumila very closely; Isoloma divergens simulates Diellia erecta; and Odontosoria bifida is a surprisingly close replica in frond habit of Diellia mannii. Of the davallioid ferns, Nephrolepis brownii, of the Marquesas Islands, perhaps resembles Diellia the most and, in fact, was originally described as a species of Diellia (Brown and Brown, 1931). Diels (1902) tentatively placed one of the species also as a Humata, a genus closely related to Davallia. There are likewise species of Asplenium, especially in the group of rock-spleenworts (Christ, 1910), that have a near-resemblance to the frondhabits of some Diellia forms and species. With such scattered examples of gross resemblances it was concluded that mere frond habit was inconclusive as a comparative character in this case.

The specific form of leaflets or "pinnae" seems not much more useful as a clue to relationships. These structures may be analyzed in regard to such features as the pinna-attachments, pinna-bases, laminar margins, and venation. Adaptations of such techniques as clearing and staining are found to be most revealing in this connection. On the species level, venation is quite important in Diellia, since two of its species possess complex, highly developed, reticulate venation that becomes evident even in the very young leaves of sporophytes grown from spores. The genus has probably more gross resemblances of the pinnae to certain of the lindsaeoid ferns than to any others. In the Asplenia. ceae, areolate venation, similar pinna-shapes and vein-patterns, as well as sori which are marginal as in Diellia, all occur, but these features are not known to exist in the same combination as they do in Diellia.

The detailed anatomical structure of the fern lamina, its epidermis, mesophyll, and hairs, is a good source of evidence in some cases. In the genus Pyrrosia the stomata and associated cells were long ago shown to be valuable keys to relationship at the species level. But such peculiar structures as the epidermal fibers found in the Vittariaceae and in certain species of Adiantum and Pteris resemble those of species of Selaginella so much that apparently even such a seemingly unique feature as this can be attained along totally different evolutionary lines. In the study of Diellia the cellular structure of the lamina seems to offer no consistent trend or pattern within the assemblages involved in this problem. The mesophyll appears to be subject to changes in number of layers, shape of cells, and the development of inter-cellular spaces in response to different environmental factors. However, the value of the laminar trichomes appears to be much greater, and this character may well be applicable to a large number of other taxonomic problems. Although many higher ferns are described as having glabrous leaf blades and although the laminar hairs may be shed shortly after the maturation of the tissues of the leaf, in none of the cleared preparations of "glabrous" ferns examined carefully in this or other studies of ferns has these trichomes 
failed to be present; they are particularly conspicuous on young fronds. In Diellia these hairs are distinctive, consisting of a row of three cells, the two upper ones globular in form and glandular and the supporting cell urn-shaped. These hairs match closely those of Asplenium trichomanes, $A$. normale, $A$. macraei, Ceterach dalhousiae, and Camptosorus rhizophyllus, but contrast strongly with such other Aspleniaceae as Loxoscaphe spp., Phyllitis spp., and members of other species-groups in Asplenium. Comparison of the sporophytic hairs of Diellia (which are markedly different from the trichomes of its gametophyte) with those of the lindsaeoid and davallioid ferns reveals significant and conspicuous differences. Hairs of lindsaeoid ferns of three genera studied are uniformly 2-celled, the cells non-inflated and long-cylindrical in form. Those of the davallioid genera tend to comprise a variable number of cells, but the cells are uniformly non-inflated, and the hairs frequently show lateral branching.

The sorus of Diellia presents an excellent demonstration of convergent evolution in the ferns. Although the mature structure of this sorus may be described exactly as in the lindsaeoid ferns, i.e., marginal, with an "upper" and a "lower" indusium, the ontogenies of the sori in the two groups of ferns turn out to be very different. In Diellia the receptacle and "lower" indusium arises well behind the line of marginal initials of the leaflets, and a socalled "upper indusium" is actually the leaf-margin. In the lindsaeoid ferns, by contrast, the marginal cells give rise directly to the receptacle and the two indusia arise behind the margin on the adaxial and abaxial sides of the embryonic lamina respectively. The sorus of the lindsaeoid ferns is truly marginal in ontogenetic origin therefore, whereas that of Diellia is superficial. The actual details of soral ontogeny in respect to the formation of the sporangium-producing cells of the receptacle and the development of the indusium are like those of $A s$ plenium and Phyllitis. The past interpretations of the sorus of Diellia are now shown to be erroneous on the basis of ontogenetic evidence; and it seems very likely that a number of similar cases may be revealed in the future in other so-called "marginal" ferns. Although Bower has stressed what he called the "slide" of the sorus from the marginal to the abaxial and superficial position in fern evolution, insufficient attention has been given to what might be called a "reverse phyletic slide," i.e., the phylogenetic migration of sori from a superficial position to a marginal position. The number of ferns which possess marginal sori that can be expected to prove entirely superficial in origin as in Diellia, both ontogenetically and phylogenetically, is likely to be a large one. In the Hawaiian Athyrium macraei, the extremes of variation within one population may show, on the one hand, sori which are terminal on short extensions of the margin and, on the other, sori which are superficial along one side of the vein (as is the usual case in the remaining 600 or so species of this genus). Yet Bower argued that the individuals of this species which possess the marginal condition were related to the marginally soriate Dennstaedtia, and upheld the placing of these individuals in a separate genus, Deparia (1928). He also placed Cionidium moorei, of New Caledonia, in the "genus" Deparia, because of its similar sori, although in all other respects Cioni. dium appears to be actually a Tectaria (a large genus with some 200 species with usually round sori which are indusiate and dorsal) and most closely related specifically to $T$. seemannii (Copeland, 1947). Dictyoxiphium panamense, a Central American fern with marginal coenosori (in aspect like those of certain species of Lindsaea, for instance), also appears to be an evolutionary offshoot of the aspidiaceous genus Tectaria. The familiar submarginal sori of the North American Dryopteris marginalis, a species in a large genus with mostly medial, superficial sori, show a tendency toward outward soral migration which has culminated elsewhere in $D$. deparioides, of northern India and Ceylon; in the latter species the sori are borne on narrow projections of the margin more than a millimeter in length. In the genus Polypodium, Maxon (1911) described $P$. podocarpum from Central America in which the sori are also located on the apices of projecting marginal teeth and the genus Prosaptia provides a splendid example of the marginward migration of sori in a group of ferns (the grammitids) with sori originally dorsal. The marginal sori of certain genera of Vittariaceae, e.g. Vittaria, are likewise probably derived from a superficial soral condition. Thus the sorus is by no means always a conservative feature. It is to be hoped that ontogenetic studies will be made in the future on these and other ferns from the standpoint of marginal vs. superficial origin to determine the actual situations. Also such soral characters as indusia, their presence or absence (as in the cyatheaceous genera Alsophila and Hemitelia) and their detailed structure, the fusion of sori into coenosori (and the division of coenosori into discrete sori), the structure of fertile veins, the cellular composition and maturation of receptacles, the paraphyses, and other aspects, all need critical study for conclusive determination of their real value in the taxonomy of the various lines of fern evolution.

The organization of the leptosporangium appears to offer one of the most fertile and available sources of taxonomic evidence. Not only its mature structure but also its ontogeny show unexploited diversity. Present indications suggest that the value of sporangial characters is far from having been realized and, in fact, that even the general descrip. tions of leptosporangial ontogeny provided by current morphological textbooks may be misleading (e.g., Eames, 1936). In the genera Diellia, Nephro- 
lepis, Asplenium, and Ceterach (as well as some other genera in other families not involved in this study), the formation of the cells of the sporangial stalk appears to be entirely by a process of intercalary cell division, rather than by the generally described addition of successive stalk cells from an apical cell. Furthermore, there seems to be no real evidence for the current view that the tapetum of the leptosporangiate ferns is formed from "potentially sporogenous" cells, since the formation of the tapetal cells is carried out in the same manner as the formation of the outer wall layer. The tapetum in these plants appears actually to be an inner wall layer cut off by a tetrahedral mother cell in the same way as the outer wall layer; only after the two wall layers have been formed does the mother cell appear to change its potential activity to that of sporogeny. These are points of fundamental botanical importance that need further clarification. In Diellia and such asplenioid ferns as Asplenium and Ceterach the first wall formed in the projecting sporangial initial is transverse, but in the davallioid ferns, Davallia and Nephrolepis, the first wall is strongly oblique. Intercalary divisions parallel to and below the original transverse wall formed in the first type give rise to a one-rowed stalk; in the case of the davallioid ferns, Davallia and Nephrolepis, however, divisions on either side of the oblique initial wall produce a characteristic tworowed stalk. In the lindsaeoid ferns a still different condition exists, and the stalk develops into a threerowed structure. Thus the stalk and its mode of formation alone may be a valuable feature in taxonomic and phylogenetic analysis. The capsule is also unexpectedly provided with diversification in these higher ferns. In the asplenioid ferns and in Diellia the vertical annulus was found to comprise a high number of the specialized thick-walled cells, an average of 18. Another interesting peculiarity here was the absence of thin-walled, unmodified cells between the annulus and stomium, the thickened cells of the stomium being directly connected to the thickened cells of the annulus. The davallioid capsule in the genera (5) of Davalliaceae studied, on the other hand, shows not only a conspicuously low number of annulus cells, usually about 12 , but a stomium manifestly separated from the annulus by three or four unmodified, thin-walled cells. The capsule of the lindsaeoid ferns not only possesses such a separation of the stomium from the annulus, but the annulus tends to be oblique, i.e., offset at the juncture of the capsule with the sporangial stalk. In solving this problem of relationship, therefore, characters of potential value were detected in the leptosporangium, and it should be recommended as a possible source of evidence in future taxonomic work in other difficult generic groups.

Without doubt modern eytological techniques will also provide very significant contributions to fern phylogeny and taxonomy. The chromosome numbers of ferns are usually quite high, and may, therefore, as a rule be studied more easily in meiosis than in mitosis. I have found, however, that the use of some chromosome-shortening agent gives considerable assistance in making the somatic squashes. The important work of Manton (1950) has already given a preliminary insight into the potential value of chromosomes at the generic level in such problematic groups as Thelypteris (Lastrea), Gymnocarpium, Phegopteris, Athyrium, and Blechnum. The lack of extensive precise information of the kind recently provided us, however, indicates that fern taxonomists themselves might profitably participate in the quest for such cytological knowledge, whenever possible, in order to broaden the bases upon which evidence can be drawn. In the genus Diellia the chromosome number is $n=$ 36. Manton found this base number to be characteristic also for 13 species of Asplenium of temperate regions as well as of the aspleniaceous genera Ceterach and Phyllitis.

Thus, in this instance, the cytological evidence proved to be in harmony with that derived from habitat, spores, gametophytes, young sporophytes, rhizomes, scales, leaf-axes, frond structure, lamina, hairs, soral ontogeny, and capsular structure. Such obvious but misleading superficial features as leaf structure and gross form of the mature sorus of Diellia primarily led to its diverse and repeatedly erroneous, taxonomic and phylogenetic treatment over nearly a century. Diellia, then, is a fern genus which well illustrates for this symposium the type of convergent evolution that has happened repeatedly among the ferns. In a sense it seems unfortunate that there is such manifest diversity in conspicuous characters as sorus and frond-form of ferns, as casual workers have sometimes tended to overlook the large number of more revealing characters such as those used in working out the solution of this problem. Diellia, however, exhibits only one of many cases of simultaneous convergent evolution in several gross characters; a spectacular example might be mentioned from Fiji, for instance, where two unrelated ferns, Loxoscaphe gibberosum and Davallia feejeensis, are so alike in habit, frond and pinna structure, and soral morphology that they are repeatedly confused with each other in herbaria.

In the case of Diellia it has been possible not only to determine the real affinities but also to postulate with considerable certainty the actual ancestral type-the generalized type of the "blackstemmed" rock-spleenwort group of Asplenium trichomanes. Evolution within Diellia has evidently been a diversification along several different lines away from an original Diellia-type which resembled, except for the orientation of sori and the marginal veinlet commissures associated with the new soral position, the ferns of the familiar "black-stemmed" 
spleenworts of temperate regions in which the sorus occupies the entirely different medial position characteristic of the Aspleniaceae.

The value of no taxonomic character in ferns can be known until the character has been exploited in respect to a particular group, and there is no reason why any character should be invariably dependable or undependable. In the solution of taxonomic problems it would, therefore, seem advisable to extend the number of points of comparison to all of those within the technical capacity of the taxonomist to evaluate and utilize. An endeavor like this may also well reveal facts of a fundamental nature which can be useful in other botanical disciplines. Such an approach is sounder than the mere acceptance, as if already established, of the value of a limited number of "key" characters such as sorus structure, and dealing with these alone in order to make a merely "useful" or "convenient" system of names. The goal of fern taxonomy is not just a system of names to serve the immediate purposes of those who file specimens in herbaria or make floralistic lists, but a valid phylogenetic system. In the harmonious combination of the viewpoints of the physiologist, morphologist, anatomist, geneticist, and cytologist, exists the possibility of developing a broadly founded phylogeny and taxonomy of the Filicineae that would be both acceptable and useful to all types of biologists.

\section{SUMMARY}

The characters used as criteria for determining relationships of ferns are surveyed in reference to a single problematic genus, Diellia, which historically has been associated with several unrelated groups of ferns primarily on the basis of sorus and leaf form. It is shown in this case that other characters must be utilized to demonstrate affinities, and that it seems advisable to extend the number of points of comparison to all those within the technical capacity of the taxonomist to evaluate and utilize. A number of the characters discussed here will require future analysis and exploitation in the study of ferns. In Diellia, the evidence derived from habitats, spores, gametophytes, young sporophytes, rhizomes, scales, leaf-axes, frond structure, lamina, hairs, soral ontogeny, capsular structure, and cy. tology, eliminates the confusion regarding its affinities, and furthermore shows clearly that its relationships are with the Aspleniaceae, and specifically with the "black-stemmed" rock-spleenworts in the group of Asplenium trichomanes. It is believed that a valid phylogenetic system of ferns can result from the harmonious combination of the viewpoints of workers in the several botanical disciplines.

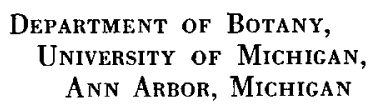

\section{LITERATURE CITED}

Arbelíez, E. P. 1928. Die Natürliche Gruppe der Davalliaceen (Sm.) Kfs. unter Berücksichtigung der Anatomie und Entwicklungsgeschichte ihres Sporophyten. Bot. Abhand. 14: 1-96.

Bower, F. O. 1928. The ferns (Filicales). Vol. III. The leptosporangiate ferns. Cambridge University Press. Cambridge.

Brown, E. D. W., and F. B. H. Brown. 1931. Flora of southeastern Polynesia. II. Pteridophytes. B. P. Bishop Mus. Bull. 89.

Christ, H. 1910. Die Geographie der Farne. G. Fischer. Jena.

Christensen, C., 1925. Revised list of Hawaiian Pteridophyta. B. P. Bishop Mus. Bull. 25.

Copeland, E. B. 1929. The oriental genera of Polypodiaceae. Univ. California Publ. Bot. 16: 45-128.

1947. Genera Filicum, the genera of ferns. Chronica Botanica Company. Waltham, Massachusetts.

Diels, L. 1902. Polypodiaceae. In Engler \& Prantl, Die natürlichen Pflanzenfamilien. Bd. 1 (Abt. 4) : 139-339. Leipzig.

Eames, A. J. 1936. Morphology of vascular plants. McGraw-Hill Book Co. New York.

Hillebrand, W. 1888. Flora of the Hawaiian Islands. C. F. Winter. Darmstadt.
HoOKer, W. J., ANd J. G. BaKer. 1883. Synopsis Filicum, or a synopsis of all known ferns. 2nd ed. London.

Holttum, R. E. 1949. The classification of ferns. Biol. Rev. 24: 267-296.

Manton, I. 1950. Problems of cytology and evolution in the Pteridophyta. Cambridge University Press. Cambridge.

Maxon, W. R. 1911. A remarkable new fern from Panama. Smithsonian Misc. Collections 56, No. 24.

Moone, T. 1857. Index Filicum. London.

OcurA, Y. 1938. Anatomie der Vegetationsorgane der Pteridophyten. In Linsbauer's Handbuch der Pflanzenanatomie. Abt. II, 7 (2) : Archegoniaten. Gebruder Borntraeger. Berlin.

Овтн, O. 1936. Morphologische und Physiologische Untersuchungen an Farnprothallien. Planta 25: 105-150.

Stokey, Alma G. 1951. The contribution by the gametophyte to the classification of the homosporous ferns. Phytomorphology 1: 39-58.

Wagner, W. H., JR. 1950. The habitat of Diellia. Amer. Fern Jour. 40: 21-32. 1952. The fern genus Diellia. Univ. California Publ. Bot. 26: 1-212. 